\title{
Coupled surface water and groundwater model development and calibration using MIKE SHE for the Greater Bunbury region in south-west Western Australia
}

\author{
M. S. Alam ${ }^{\text {a }}$ \\ ${ }^{a}$ Urban Water, Science and Planning, The Department of Water and Environmental Regulation \\ Email: muhammad.alam@dwer.wa.gov.au
}

\begin{abstract}
The Greater Bunbury region in south-west Western Australia is distinguished by low-lying lands, shallow groundwater table, regular winter inundation and extensive network of agricultural drains. Department of Planning, Lands and Heritage released the Greater Bunbury Strategy 2013 which aims to allow the region to grow from 83,598 people (2011 Census) to at least 150,000 people. It assigned Department of Water to develop a Drainage and Water Management Plan (DWMP) to make the growth sustainable. A key component of the DWMP is the development of a fully distributed, physically-based coupled surface water and groundwater interactions model using MIKE SHE hydrologic modelling system. This is to accurately reproduce groundwater levels and aquifer discharge to rivers and drains and understand the hydrological processes. Hence the modelling outcomes will be used in outlining water management and land use change options. This study focuses mainly on the conceptualization, development and calibration of the model. The model covers a study area of $497 \mathrm{~km}^{2}$ that extends from the Darling Scarp in the east to the coast in the west, and ranges in elevation from $60 \mathrm{mAHD}$ to $0 \mathrm{mAHD}$. Thirty-five years of distributed daily climate data (1980-2014) were used to calibrate the model. It comprised of process models for evapotranspiration, overland flow, unsaturated flow, groundwater flow and river flow to capture the major processes in the hydrologic cycle. It was built on a $150 \mathrm{~m}$ regular grid and the thickness of its saturated zone varies from $160 \mathrm{~m}$ in the north to $800 \mathrm{~m}$ in the south. The saturated zone was divided into eight computational layers to accommodate the unconfined Superficial Aquifer, and the confined Leederville and Yarragadee Aquifers. The model was calibrated using a total of 62,13 and 6 bores installed in the Superficial Aquifer, Leederville Aquifer and Yarragadee Aquifer, respectively. The calibration was performed based on comparisons of observed and modelled groundwater heads and river flows. Model results are generally consistent with field observations. An intrinsic difficulty in representing anisotropic Guildford Clay Formation within the Superficial Aquifer limited model performance otherwise excellent agreements are seen in general. The calibration targets outlined were achieved for the Superficial Aquifer with a scaled mean sum of residuals (SMSR) $-0.25 \%(-0.1 \mathrm{~m})$ and a scaled root mean square error of $1.87 \%$. The water balance estimation for the model domain showed an error of $0.01 \%$, which satisfied the criteria of a water balance error $<0.05 \%$. These calibration statistics are within the acceptance range as mentioned in the Murray Darling Basin Commission guidelines and illustrate the level of general reliability of the model.
\end{abstract}

Keywords: Integrated groundwater and surface water model, MIKE SHE, hydrologic cycle, Greater Bunbury, aquifer 
M.S. Alam, Coupled surface water and groundwater model development and calibration using MIKE SHE for the Greater Bunbury region in south-west Western Australia

\section{INTRODUCTION}

The Western Australia Planning Commission (WAPC) identified the Greater Bunbury region as a potential for urban growth. This area is located around $160 \mathrm{~km}$ south of Perth which is expected to grow from 83,598 people (2011 Census) to at least 150,000 people. The Department of Planning, Lands and Heritage assigned the Department of Water and Environmental Regulation (DWER) to develop a Drainage and Water Management Plan (DWMP). The information to be provided in the DWMP on surface water and groundwater will be integrated into a decision support system for water resource and land use managements. The prime component of the DWMP is the development of a fully distributed, physically-based coupled surface water and groundwater interaction model using a robust hydrological modelling system. The model will be used for accurately reproducing groundwater levels, aquifers discharge to rivers and drains. This model will also be used in simulating the responses of groundwater to urbanisation and changes in climate. The current study focuses mainly on the conceptualisation, development and calibration of the model.

\subsection{Study area}

The Greater Bunbury hydrological study area comprises about $497 \mathrm{~km} 2$ of predominantly agricultural land located on the Swan Coastal Plain $160 \mathrm{~km}$ south of Perth (Figure 1). It extends from the Darling Scarp and the Whicher Scarp in the east to the Indian Ocean and the Leschenault Estuary in the west, and bounded by the top

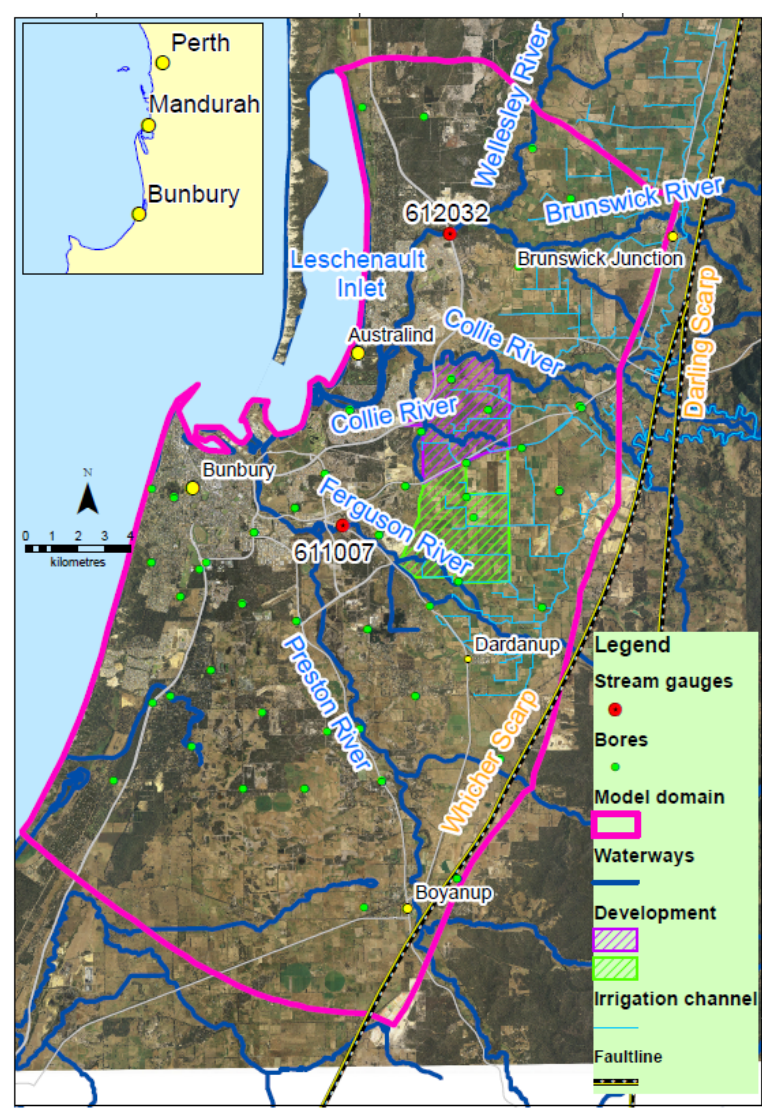

Figure 1. The Greater Bunbury study area of the Leschenault Estuary in the north and Boyanup in the south. The topography is characterised by gentle undulating dunes in the west and Pinjarra Plain in the east shifting into the Darling and Whicher scarps. The study area on the Swan Coastal Plain can be divided into four geomorphic units. The Quindalup Dune System, the Spearwood Dune System, the Bassendean Dune System and the Pinjarra Plain. These units correspond respectively to the Safety Bay Sand, the Tamala Limestone, the Bassendean Sand and the Guildford Clay Formation (Figure 2). The dune systems run parallel to the coastline creating lakes and swamps within the lowlying interdunal depressions. The Quindalup Dunes occur along the coastal strip. The maximum elevation is around $60 \mathrm{mAHD}$ (meter Australian Height Datum) and it is up to around $1 \mathrm{~km}$ wide. The Spearwood dune is adjacent to the Quindalup Dunes or the Leschenault Estuary where it reaches a maximum elevation of $55 \mathrm{mAHD}$. The Bassendean Dunes has a maximum elevation of $40 \mathrm{mAHD}$ and it is up to $10 \mathrm{~km}$ wide between the Spearwood Dunes and the Pinjarra Plain. The Pinjarra Plain extends from the Darling or Whicher Scarp in the east to the Spearwood Dunes in the west, and occurs within the gaps of Bassendean dunes. The maximum elevation reaches up to $60 \mathrm{mAHD}$. The area is drained predominantly by Wellesley, Collie, Ferguson and Preston river systems flowing generally from the Darling Scarp to the Leschenault Estuary. There exists around $200 \mathrm{~km}$ long open channel system irrigation drain network in the Collie River Irrigation District on the Pinjarra Plain (Harvey Water, 2008). It is fed by Wellington Dam of the Collie River located around $8 \mathrm{~km}$ upstream of the eastern boundary.

\subsection{Climate and land uses}

The region has a Mediterranean climate with hot dry summers and cool wet winters. The average annual rainfall varies from about $750 \mathrm{~mm}$ near the coast to about $900 \mathrm{~mm}$ along the Darling Scarp. The average annual evaporation is about $1400 \mathrm{~mm}$. The majority of the rainfall occurs during the five months, May to September, while the rainfall exceeds evaporation. Seventy-five per cent of the study area has been cleared vastly for grazing beef and dairy cattle. The reminder encompasses urban, agriculture, industrial and conservation areas, and areas of native vegetation and plantation. 
M.S. Alam, Coupled surface water and groundwater model development and calibration using MIKE SHE for the Greater Bunbury region in south-west Western Australia

\subsection{Hydrogeology}

The Swan Coastal Plain sedimentary deposits within the study area consist of four aquifer systems. These are the Superficial, Leederville, Yarragadee and Cattamarra. The main focus of the current study is on the interactions between surface water and groundwater. The Cattamarra which is the deepest aquifer within the region plays an insignificant role on the interactions. It was not considered for this study. The geology and hydrology of the upper three aquifers of the region are summarised in Table 1. The 3D block model for the study area is also presented in Figure 2. It was taken from the conceptual model report (DWER, 2017) produced for the region which was a prerequisite of the current study. The block model was developed based on the interpretation and classification of lithological logs, as well as the original stratigraphic description of logs.

Table 1. Stratigraphy and Hydrogeology for the region

\begin{tabular}{|c|c|c|c|c|c|}
\hline Era & Period & Formation & $\begin{array}{l}\text { Aquifer } \\
\text { system }\end{array}$ & $\begin{array}{c}\text { Max. } \\
\text { thickness }\end{array}$ & Stratigraphy \\
\hline \multirow{5}{*}{$\begin{array}{l}\frac{U}{0} \\
N \\
\stackrel{0}{0} \\
\cup\end{array}$} & \multirow{5}{*}{ Quaternary } & \multirow{5}{*}{$\begin{array}{l}\text { Superficial } \\
\text { formations }\end{array}$} & \multirow{5}{*}{ Superficial } & \multirow{5}{*}{$55 \mathrm{~m}$} & Safety Bay Sand \\
\hline & & & & & Tamala Limestone \\
\hline & & & & & Bassendean Sand \\
\hline & & & & & Guildford Clay \\
\hline & & & & & Yoganup Formation \\
\hline \multirow{5}{*}{ 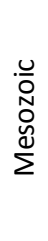 } & \multirow{4}{*}{ Cretaceous } & \multirow{3}{*}{$\begin{array}{l}\text { Leederville } \\
\text { Formation }\end{array}$} & \multirow{3}{*}{ Leederville } & \multirow{3}{*}{$435 \mathrm{~m}$} & Mowen \\
\hline & & & & & Upper Vasse \\
\hline & & & & & Lower Vasse \\
\hline & & & & $100 \mathrm{~m}$ & Bunbury Basalt \\
\hline & Jurassic & $\begin{array}{l}\text { Yarragadee } \\
\text { Formation }\end{array}$ & Yarragadee & $750 \mathrm{~m}$ & Yarragadee Formation \\
\hline
\end{tabular}

However, the interpreted formations displayed in the figure are consistent with the geological understanding on the region. The Yarragadee Formation is thickest in the south-east and thins towards the north-west. It is divided into four units based on distinct lithology and characteristics (WC, 2005). The unit 1 does not exist in the study area and hence not presented in the block model. The Bunbury Basalt overlies the Yarragadee Formation. It acts like an aquitard as it restricts water movements between the Yarragadee aquifer and the overlying Leederville

comprises the geological units known as the Mowen, Upper Vasse and Lower Vasse. It underlies the superficial formations except for some area in the south-west where the formation was eroded away. It is thickest in the east along the border and in the north near the Leschenault Inlet. It overlies the Yarragadee Formation in most of the area and the Bunbury Basalt where it is present. The superficial formations unconformably overly the

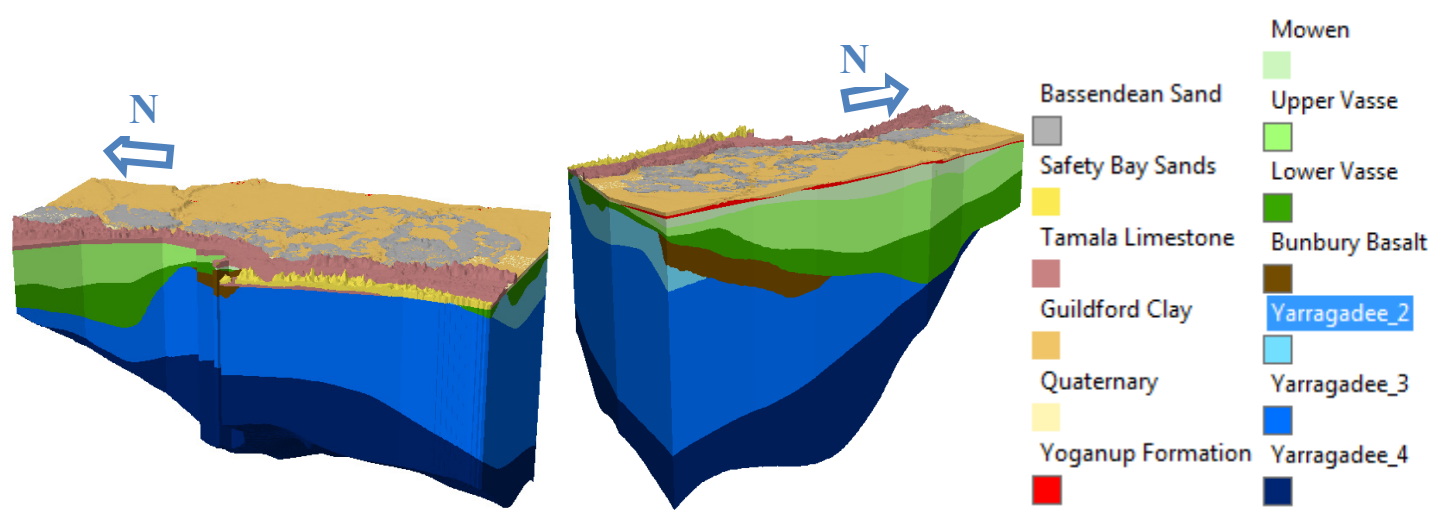

Figure 2. 3D block model showing the geological interpretation of the region

Yarragadee Formation near the coast, and Bunbury Basalt and Leederville Formation in the rest of the region. It consist of tertiary and quaternary sediments which form an unconfined aquifer termed as the Superficial Aquifer. It consist predominantly of clay and sand in the east, and of sand and limestone in the west. The analysis of the pumping tests for the superficial formations reveals that the Superficial Aquifer is inhomogeneous and anisotropic. The pumping tests and the variation in lithology indicate that it is a multilayer aquifer composed of aquitards and aquifers (Deeney, 1989). The recharge in the Superficial Aquifer predominantly occurs via direct rainfall during winter on the Swan Coastal Plain. The recharge is prominent in areas with a sandy profile covered by Bassendean Sand, Tamala Limestone or Safety Bay Sand, and less in areas covered by Guildford Clay which acts as a minor aquitard. The recharge in this aquifer is also occurred via upward leakage from the Leederville in the central part of the region and from Yarragadee near the coast. Vertical fluxes, including rainfall recharge and evapotranspiration are dominant in this region. 
M.S. Alam, Coupled surface water and groundwater model development and calibration using MIKE SHE for the Greater Bunbury region in south-west Western Australia

\subsection{Hydrology}

Figure 1 displays the major surface water features in the study area. There are five major waterways: the Preston River, the Ferguson River, the Collie River, the Brunswick River and the Wellesley River. All of them are originated from the Darling Scarp. The Collie River runs across the study area from the east to the Leschenault Inlet in the west with a Brunswick River as a tributary that joins near Australind. The Preston River drains to the Leschenault Inlet after receiving inflows from Ferguson River and other tributaries. The major waterways within the region are fed by a complex network of tributaries, drains and irrigation channels.

\subsection{Model selection for surface water and groundwater interactions}

The main objective of the study was to develop and then calibrate a surface water and groundwater interactions model representing the Greater Bunbury region which will later will be used in assessing the influence of development and climate change on the interactions between aquifers (predominantly the Superficial Aquifer) and surface water. MIKE SHE modelling framework was selected to carry out the study. The framework provides a single modelling platform which allows an integrated simulation environment for open channel hydrodynamics, overland flow and unsaturated zone and saturated zone processes to capture groundwater movements. It implements a finite difference approach to solve the partial differential equations describing the overland flow, channel flow and saturated zone flow. It uses analytical solutions for describing interception and evapotranspiration. The model calibration was done following the performance criteria mentioned in Murray Darling Basin Commission guidelines for groundwater flow modelling (Middlemis, 2000).

\section{THE CONCEPTUAL MODEL}

The conceptual 3D model for the study area is shown in Figure 2. It was developed based on extensive literature review, interpretation exercise undertaken on lithological logs and stakeholder consultation. The top three aquifers were considered for the model construction which interact with surface waters across the model domain. The classifications of the aquifers and geological formations has already been mentioned in the Hydrogeology section of this paper. Horizontal hydraulic conductivities vary from around $0.1 \mathrm{~m} /$ day in clayed formation, $20 \mathrm{~m} /$ day in sandy formations and around $30 \mathrm{~m} /$ day in the Tamala Limestone. The numerical coupled surface water and groundwater model was developed based on this conceptual 3D model.

\section{MODEL CONSTRUCTION}

The transient numerical model for the Greater Bunbury region was constructed using MIKE SHE software package (version 2016). The model consisted of unsaturated zone, saturated zone, channel flow and overland flow model components. It was configured with regular grid cells. The grid developed for the model domain is discretized to 246 rows and 167 columns covering a total area of $497 \mathrm{~km} 2$ with a uniform cell size of $150 \mathrm{~m} \times 150 \mathrm{~m}$.

A multi-layer, heterogeneous and anisotropic 3-D hydrogeological model was developed for the saturated zone of the study area by vertically discretizing the model domain into 8 computational layers (Computational Layers 1-8). The computational layers extend to a depth around $750 \mathrm{~m}$ below the land surface. The top three computational layers (Computational Layers 1-3) were developed within the Superfical Aquifer system. The Computational Layers 4-8 were constructed to define geological layers for the Mowen, Upper Vasse, Lower Vasse, Bunbary Basalt and Yarragadee. The vertical discretization of the superficial formations was required for this study, as the pumping tests and variation in lithology within the Guildford Clay Formation indicated that it acts like an aquitard. This phenomenon was presented in the model by introducing a $1 \mathrm{~m}$ thick Computational Layer 2 within the Superficial Aquifer system. This computational layer was developed to represent the aquitard nature of the Guildford Clay Formation (GCF). It was positioned $5 \mathrm{~m}$ below the minimum groundwater level. A network of monitoring bores was drilled across the GCF, with a shallow bore and a deeper bore at each site. The shallow bores were drilled at $5 \mathrm{~m}$ depth. The interpretation and classification of lithological logs of tandem bores indicate the presence of the aquitard below the shallow bores. The average minimum groundwater level map for the extent of the GCF indicate that the minimum groundwater level is close to the surface in many patchy areas. The placement of the Computational Layer $2,5 \mathrm{~m}$ below the minimum groundwater level ensures all shallow bores within the GCF placed above the aquitard. The 3-D Boussinesq equation was adopted for simulating the saturation zone flow. Three types of boundary conditions were assigned to the computational layers: fixed head, no-flow and time-varying head boundary conditions. In the top three computational layers representing the Superficial Aquifer, a zero mAHD, fixed head boundary condition was applied representing the coast to the western edge. A no-flow boundary condition was applied at the northern, southern and eastern edge, as groundwater contours are perpendicular around the northern and 
southern edge, and the Darling Scarp acts as a hydraulic barrier at the eastern edge. In the Computational Layers 4-6 to describe the Leederville Aquifer, western edge was treated with 0 mAHD fixed head boundary condition and the northern and southern edge were treated with no-flow boundary condition, whereas a timevarying boundary condition was applied at the eastern edge. The Computational Layer 8 was used to describe the Yarragadee Aquifer which adopted a no-flow boundary condition in the northern edge, a time-varying boundary condition in the southern, the eastern and part of the western edge (below the Leschenault Inlet), and 0 mAHD fixed head adjacent to the Leschenault Inlet. A correction on coastal heads, to convert saline water heads to fresh water heads, was applied to the time-varying boundary condition for the southern portion of the western edge using a simple equation developed by Kohout (1964).

The five major rivers mentioned in the Hydrology section were considered to model using MIKE11 framework. The network, cross section and boundary files were developed. The cross section file was composed of surveyed cross sections and digital cross sections extracted from $1 \mathrm{~m}$ DEM. Boundary conditions for these major rivers were set using inflows at the upstream end and water levels at the downstream ends. The MIKE11 model also received inflows from overland flow and drain cells. The MIKE11 model adopted a 1D implementation of the fully dynamic Saint-Venant equations for solving stage and discharge at every alternate computational node. The overland flow was modelled using the diffusive wave approximation of the SaintVenant equations.

The 2-layer water balance model option was selected in MIKE SHE to estimate evapotranspiration (ET) and recharge to the groundwater. This model is based on the formulation presented in Yan and Smith (1994) and particularly useful for areas with shallow groundwater table. This model was chosen as the groundwater within the study domain is usually near the surface.

Groundwater abstraction for all aquifers was modelled as it was shown to be one of the important contributors to the hydrologic cycle in the conceptual water balance calculations. A total of 5,344 abstraction points were included in the model, while 4,154 were unlicensed garden bores placed in the Superficial Aquifer. Among the licensed allocation bores, a number of 104, 658 and 428 bores were placed in the Superficial, Leederville and Yarragadee aquifers, respectively. The bores with an allocation of less than $1500 \mathrm{~kL} / \mathrm{yr}$ were excluded from the model as the volume extracted to be negligible. DWER's Water Resources Licensing (WRL) database was interrogated to extract current allocation of licensed bores. The extraction for each bore was assumed to be $80 \%$ of the allocation. The same database was used to develop a historical annual abstraction time series at each bore. A time series of abstraction at a daily time step was then developed considering a monthly variation in abstraction identified in the conceptual model report. The unlicensed abstraction was identified using the land use mapping within the model domain. It was considered that $30 \%$ of the residential properties had garden bores which used $800 \mathrm{~kL} / \mathrm{year}$. This consideration was consistent with the indicative water use for domestic bores mentioned in the Managing Unlicensed Groundwater Use repot (DOW, 2009). The population growth within the study area was considered as an analogue for historical unlicensed abstraction. A daily time series of abstraction was developed considering a monthly variation in abstraction and it was applied to each garden bore.

\section{DISCUSSION}

\subsection{Model calibration}

A historical simulation period of 1980-2014 was considered for the model calibration. The manual calibration process was adopted to achieve best fit between observed and modelled groundwater levels and surface water flows. A total of 81 monitoring bores were used in calibrating the model. Among them, 62, 13, and 6 bores provided water levels for the Superficial, Leederville and Yarragadee Aquifers, respectively. In this study area, 21 sites has monitoring bores in tandem, two bores at each site, one deep and one shallow, in order to monitor water levels within the Superficial Aquifer. It was done to track the presence of aquitard layers within the superficial formations. However, 47 out of 62 superficial bores, were installed in late 2013. They were drilled to support the calibration of the model with observed heads and conceptual 3D model development with lithological logs. As most of the superficial bores commenced recording water levels in late 2013, and the main focus of the study was on the superficial formations, it was decided to calibrate the model for the whole simulation period. 
M.S. Alam, Coupled surface water and groundwater model development and calibration using MIKE SHE for the Greater Bunbury region in south-west Western Australia

\subsection{Model performance}

The calibrated parameter values (horizontal and vertical conductivities) for the geological units are reported in Table 2. They are consistent with the conceptual model report. The calibration statistics for the Superficial Aquifer is presented in Figure 3. It is shown that the calibration of the superficial groundwater levels achieved a scaled root mean squared of $1.87 \%$ and a mean sum of residuals of $-0.10 \mathrm{~m}$. The scatter plot of the modelled and observed heads are also displayed in Figure 3. The calibration plots for the monitoring bores drilled in the development areas (see Figure 1) that earned the main focus of this study are shown in Figure 4. Figure 4 shows that the modelled groundwater levels, in these development areas, are generally in excellent agreements with the observed levels. Stream flow was calibrated to two gauging stations (Figure 1). An average Nash-Sutcliffe coefficient of efficiency of 0.74 was achieved. Figure 5 shows that the modelled discharge hydrographs for the Ferguson and Brunswick Rivers for 2005 compare well with the observed hydrographs. The calibration results reported indicate that the groundwater levels within the Superficial Aquifer, streamflow and their interactions are well simulated reflecting fair agreements with the observed data. The water balance for the surface water and groundwater fluxes for the whole simulation period is presented in Table 3 . It shows that the water balance error for the model domain is $0.01 \%(<0.05 \%)$ which satisfies the calibration criteria. Most of the water entering into the hydrological system through rainfall $(85 \%)$, while $76 \%$ leaves from the system through evapotranspiration.

Table 2. Optimized parameter values

\begin{tabular}{|l|l|l|}
\hline \multicolumn{1}{|c|}{ Stratigraphy } & $\begin{array}{c}K_{h} \\
(\mathrm{~m} / \mathrm{d})\end{array}$ & \multicolumn{1}{c|}{$\begin{array}{c}K_{z} \\
(\mathrm{~m} / \mathrm{d})\end{array}$} \\
\hline Safety Bay Sand & 30 & 1 \\
\hline Tamala Sand North & 15 & 1 \\
\hline Tamala Sand South & 30 & 1 \\
\hline Bassendean Sand & 20 & 0.2 \\
\hline GuildforD Clay West & 3 & 0.2 \\
\hline Guildford Clay East & 0.1 & 0.05 \\
\hline Yoganup Formation & 15 & 1 \\
\hline Quaternary & 5 & 1.2 \\
\hline Mowen & 0.1 & 0.0011 \\
\hline Upper Vasse & 3 & 0.001 \\
\hline Lower Vasse & 0.5 & 0.0013 \\
\hline Basalt & $1.00 \mathrm{E}-05$ & $5.00 \mathrm{E}-06$ \\
\hline Yarragadee & 10 & 0.0014 \\
\hline
\end{tabular}

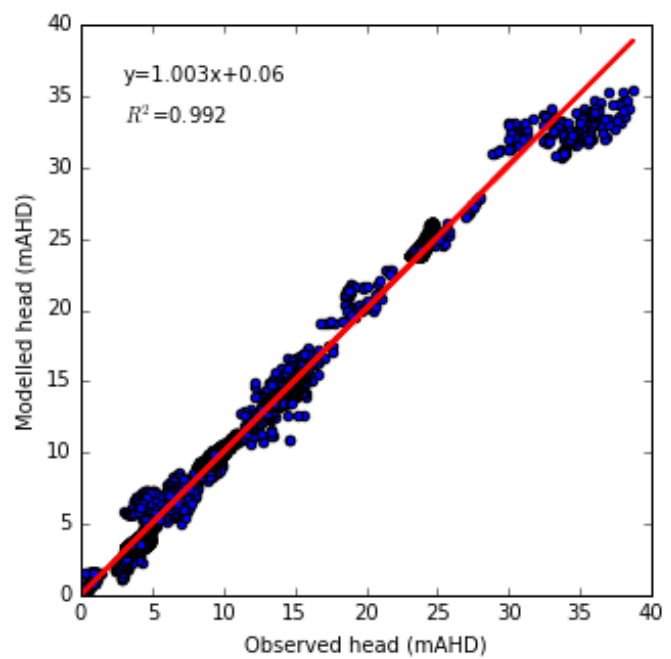

Figure 3. Calibration scatter plot
Table 3. Average annual water balance for model domain

\begin{tabular}{lrrrr}
\multicolumn{5}{c}{ System water balance (1980-2014) } \\
Flux & $\mathbf{m m}$ & $\mathbf{m m} / \mathbf{y r}$ & \multicolumn{1}{c}{$\mathbf{G L} / \mathbf{y r}$} & \multicolumn{1}{c}{$\%$} \\
\hline Rainfall & 27996 & 800 & 398 & $85 \%$ \\
Horizontal flow in & 4813 & 138 & 68.3 & $15 \%$ \\
\hline Total EVT & -24704 & -706 & -350.8 & $76 \%$ \\
Horizontal flow out & -4270 & -122 & -60.6 & $13 \%$ \\
Overland flow to rivers & -40 & -1 & -0.6 & $0 \%$ \\
Overland flow to boundary & -189 & -5 & -2.7 & $1 \%$ \\
Baseflow to rivers \& drains & -455 & -13 & -6.5 & $1 \%$ \\
Drain to river & -1064 & -30 & -15.1 & $3 \%$ \\
Abstraction & -1946 & -56 & -27.6 & $6 \%$ \\
\hline Error & 2 & 0.06 & 0.03 & 0.01 \\
$\Delta$ Storage (OL, UZ \& SZ) & 143 & 4 & 2.0 & -
\end{tabular}

\begin{tabular}{|c|c|c|c|}
\hline \multicolumn{4}{|c|}{ AQUIFER NAME:Superficials } \\
\hline Description & Observed & Modelled & Residual \\
\hline $\begin{array}{l}\text { average(mAHD) } \\
\operatorname{median}(m A H D) \\
\min (m A H D) \\
\max (m A H D)\end{array}$ & $\begin{array}{l}12.35 \\
10.34 \\
-0.0 \\
38.68\end{array}$ & $\begin{array}{l}12.44 \\
10.61 \\
0.33 \\
35.4\end{array}$ & $\begin{array}{l}-0.1 \\
-0.13 \\
-3.11 \\
4.86\end{array}$ \\
\hline \multicolumn{2}{|l|}{ Description } & Symbol & Value \\
\hline \multicolumn{2}{|l|}{ Slope } & $\mathbf{m}$ & 1.003 \\
\hline \multicolumn{2}{|l|}{ Intercept } & c & 0.06 \\
\hline \multicolumn{2}{|l|}{ Count } & n & 7425 \\
\hline \multicolumn{2}{|c|}{ Sum of squares (sqr. m) } & SSQ & 3893.0 \\
\hline \multicolumn{2}{|c|}{ Mean sum of squares (sqr. m) } & MSSQ & 0.52 \\
\hline \multicolumn{2}{|c|}{ Root mean square (m) } & RMS & 0.72 \\
\hline \multicolumn{2}{|c|}{ Scaled root mean square (\%) } & SRMS & 1.87 \\
\hline \multicolumn{2}{|c|}{ Sum of residuals $(\mathbf{m})$} & SUMR & -707.6 \\
\hline \multicolumn{2}{|c|}{ Mean sum of residuals (m) } & MSR & -0.1 \\
\hline \multicolumn{2}{|c|}{ Scaled mean sum of residuals (\%) } & SMSR & -0.25 \\
\hline \multicolumn{2}{|c|}{ Coefficient of Determination } & CD or R_Sqrd & 0.99 \\
\hline
\end{tabular}

Figure 4. Calibration statistics

\section{CONCLUSIONS}

An integrated and fully distributed regional scale hydrological model based on the coupled MIKE SHE and MIKE 11 modelling platforms was developed for the greater Bunbury region in the south-west of Western Australia. All the major hydrological processes in the land phase of the hydrological cycle such as channel flow, overland flow, unsaturated flow, evapotranspiration and saturated flow, as well as groundwater abstraction were included in the integrated hydrological model. The model was calibrated against time series of hydraulic head data obtained from 81 monitoring bores of the study area. During the calibration process, 
M.S. Alam, Coupled surface water and groundwater model development and calibration using MIKE SHE for the Greater Bunbury region in south-west Western Australia

major emphasis was given on the Superficial Aquifer and especially on the identified development areas for which a drainage and water management plan will be delivered to support the future urban growth. The calibration to surface water flow gauge readings was also undertaken for the model. The calibration resulted in an SRMS of $1.87 \%$ and an RMS of $0.72 \mathrm{~m}$ for the Superficial Aquifer and a water balance error of $0.01 \%$ for the entire model domain. These statistics satisfy the calibration criteria.
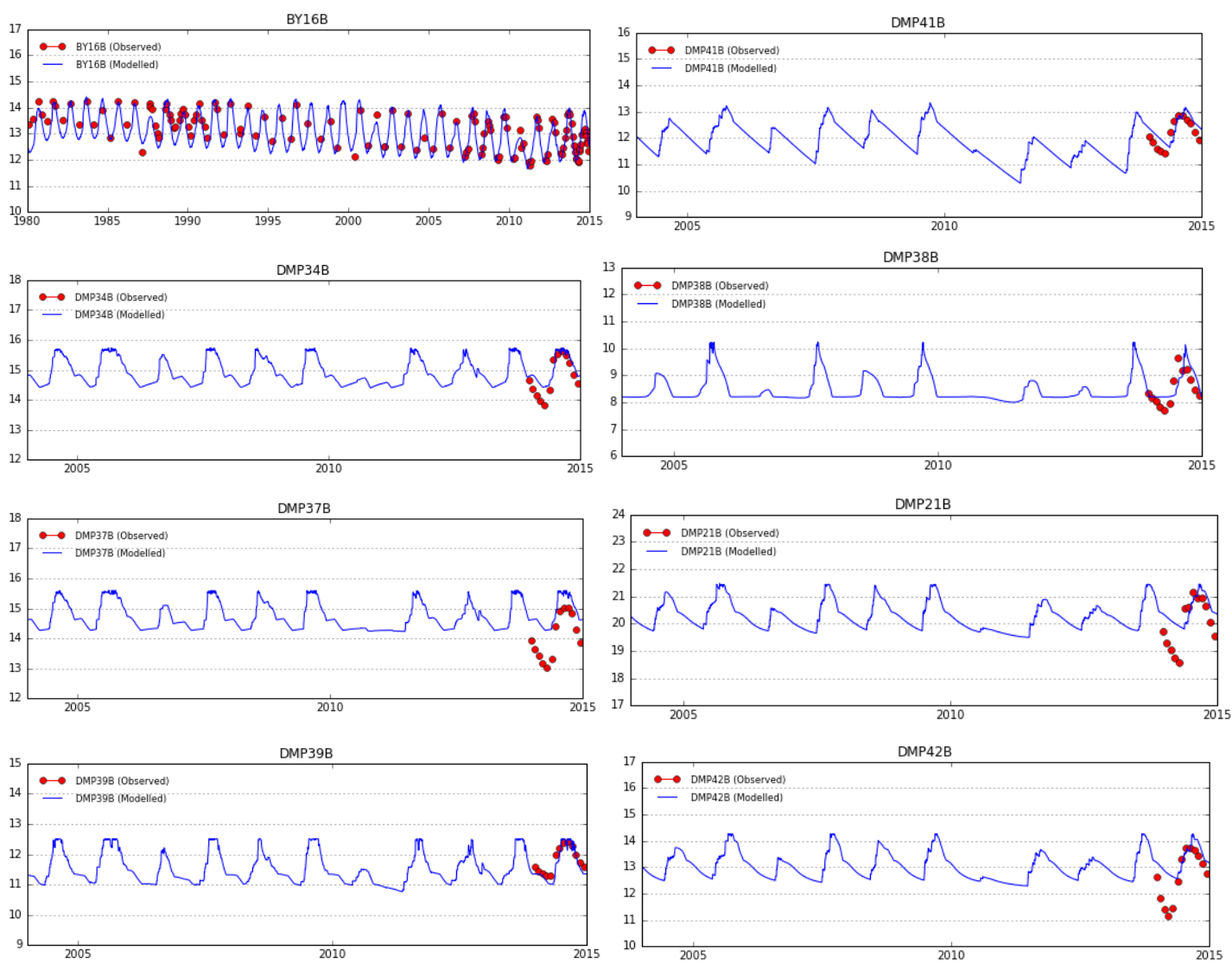

Figure 5. Calibration plots for some bores in and around the identified development areas (y-axis presents head in $\mathrm{m} \mathrm{AHD)}$

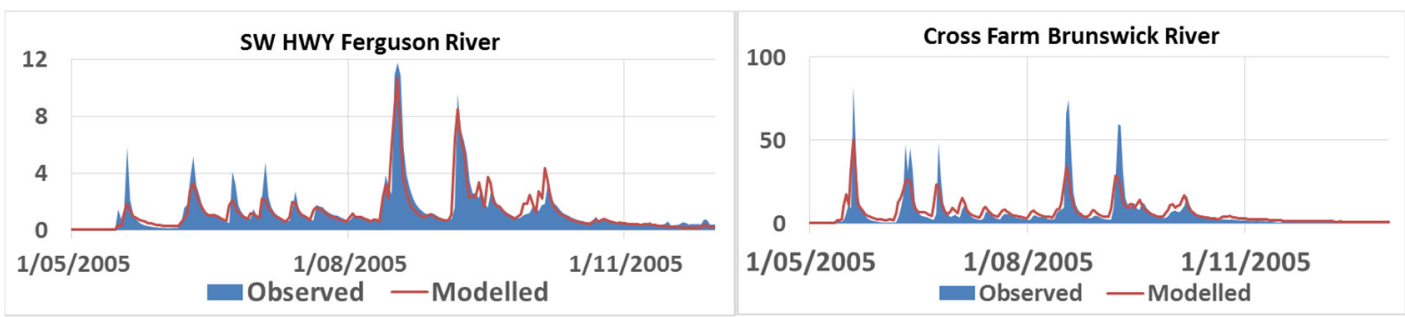

Figure 6. Calibration at Ferguson River and Brunswick River (2005); y-axis presents discharge in $\mathrm{m}^{3} / \mathrm{s}$.

\section{REFERENCES}

Deeney, A.C. (1989). Geology and groundwater resources of the Superficial Formations between Pinjarra and Bunbury. Western Australia Geological Survey, Perth, Hydrology Report No. 1988/5.

DOW (2009). Strategic policy 2.03 - Managing unlicensed groundwater use. The Department of Water, Perth, Western Australia. Series no. DWPF 2.03

Harvey Water. (2008). Report for the Collie River Irrigation System Planning, Interim Engineering Report. Harvey Water. Kohout, F.A. (1964). The flow of fresh water and salt water in the Biscayne aquifer of the Miami area, Florida. U.S. Geological Survey, Water-Supply Paper 1613-C, p. 12-32.

Yan, J. and K.R. Smith (1994). Simulation of integrated surface-water and ground-water systems-Model Formulation. Water Resources Bulletin, 30, 879-890.

DWER (2017). The Greater Bunbury hydrological studies - Conceptual model report (draft and internally reviewed). The Department of Water and Environmental Regulation, Perth, Western Australia. 